NBER WORKING PAPER SERIES

\title{
MONETARIST PRINCIPLES AND THE MONEY STOCK GROWTH RULE
}

Bennett T. McCallum

Working Paper No. 630

\author{
NATIONAL BUREAU OF ECONOMIC RESEARCH \\ 1050 Massachusetts Avenue \\ Cambridge MA 02138 \\ February 1981
}

This paper was presented at the American Economic Association meetings in Denver in September 1980. The research reported here is part of the NBER's research program in Economic Fluctuations. Any opinions expressed are those of the author and not those of the National Bureau of Economic Research. 


\section{ABSTRACT}

The main purpose of this paper is to reconsider two antimonetarist "messages" that have been prominent in recent writings on that doctrine. One of these claims that economies are likely to be unstable if a constant money growth rule, together with noncyclical fiscal behavior, is followed. The second suggests that long run effects of government deficits on aggregate demand are stronger when bond-financed than when money-financed. It is here argued that support for the second message relies upon an unjustified presumption of stability in certain macro models, when the appropriate conclusion is that instability prevails under the constant money growth rule. But the instability conclusion is also misleading as it depends upon an assumed absence of economic growth. Thus, neither message has analytical justification. The paper also stresses the importance of the natural rate of unemployment hypothesis for monetarist policy proposals and argues that some currently popular supply formulations are inconsistent with that hypothesis.

Bennett T. McCallum National Bureau of Economic Research 1050 Massachusetts Avenue Cambridge, Massachusetts 02138

(617) $868-3918$ 


\section{Introduction}

Given the influence of Milton Friedman, it is hard to keep from identifying "monetarism" with the advocacy of a policy rule that would require the money stock to grow at a constant rate and prohibit cyclical adjustments in government spending or in tax schedules. $1 /$ This identification is somewhat inaccurate since Kar1 Brunner and Allan Meltzer, the other two leading proponents of monetarism, have not always been advocates of a constant money growth rate. It may nevertheless be useful to relate one's thoughts about monetarism to Friedman's rule, as will be done in this paper. But the question that immediately arises is, what more fundamental beliefs about the economy give rise to the idea that such a rule would be socially desirable? At this more basic level there may be more agreement among monetarists than about the rule itself. In any event, it appears that there are two basic monetarist propositions that are of crucial importance, as follows. (i) Cyclical and secular movements in nominal income are primarily attributable to movements in the stock of money relative to capacity output. (ii) There is no permanent tradeoff between unemployment and inflation or any other characteristic of the path of the price level -- i.e., the natural rate of unemployment hypothesis is valid. Of course, another belief is essential -that the monetary authority can exert reasonably accurate control over the stock of money if it sets its mind to that task -- but it is not a major source of dispute with non-monetarist economists, so I will not include it on my $1 i s t . \underline{2} /$

II. The Natural Rate Hypothesis

Let us begin with a brief explanation of the importance of the second of these propositions, the natural rate hypothesis (NRH). To appreciate its significance one needs only to note that, alone, proposition (i) has nothing to say about the division of nominal income fluctuations into price and output components. Thus alone it can have no implications concerning the behavior of 
an economy's inflation and/or unemployment rates, magnitudes that are of much more inherent importance than nominal income. The crucial nature of proposition (ii) is certainly clear from the writings of Friedman -- especially (1968; 1971) -- and is stressed by Franco Modigliani, but has been neglected in many discussions of the subject. $3 /$

The other point concerning the NRH that needs to be emphasized is that its conditions are, in fact, not satisfied by numerous specifications which claim to permit no long run tradeoff. As Robert Lucas pointed out in 1972, an expectational Phillips curve -- one that relates unemployment to only the unexpected part of the inflation rate -- implies the possibility of "unlimited real output gains [unemployment reductions] from a well-chosen inflationary policy" (p. 53) unless expectations are taken to be rational. With adaptive expectations, for example, unemployment could be kept low forever if the inflation rate were made to accelerate forever. Of more significance for current debates, given the acceptance since 1972 of the rational expectations hypothesis, is the use of unemployment-inflation relationships not of the expectational variety. A prominent example is provided by the class of formulations that involves the concept of a "nonaccelerating-inflation rate of unemployment," sometimes abbreviated NAIRU. $4 /$ If there exists a stable relationship between the rate of unemployment and the acceleration of the inflation rate, as is presumed by the NAIRU concept, then evidently there are acceleration magnitudes that will yield a permanently lowered rate of unemployment. Under such formulations, therefore, an argument that rapidly accelerating monetary growth is undesirable needs to be justified by reference to some welfare criterion expressed in more detail than is usual in the monetarist literature. It seems, therefore, that NAIRU formulations should be regarded as inconsistent with monetarist doctrine. They are certainly inconsistent with the NRH itself. 
III. Monetary vs. Fiscal Policy

Having emphasized the importance of proposition (ii), let us now turn to (i) and the sizable body of literature that constrasts monetarism with "fiscalism." A prominent strand of this literature was initiated in the 1973 paper by Alan Blinder and Robert Solow, which emphasized the continuing effects -- in a mode1 with wealth terms appearing in IS and LM functions -- brought about by the ongoing issuance or retirement of government bonds required under the money growth policy rule by the government budget restraint. Significant contributions to this strand have been made by Kar1 Brunner and Allan Meltzer, Car1 Christ, Ettore Infante and Jerome Stein, and James Tobin and Willem Buiter. In a later piece, Blinder and Solow (1976) suggested that there are two significant "messages," both of which are very robust to model specification. These are "that the economy is more likely to be stable if deficits are financed by printing money than if they are financed by floating bonds" and "that the long-run effect of government spending on aggregate demand is greater when deficits are bond-financed than when theyare money financed" (1976, pp. 505-06, italics in origina1). As these messages constitute a direct challenge to monetarist proposition (i), they warrant scrutiny. The following paragraphs will argue that neither message is persuasive. Because the crucial relevant effects have to do with the nature of tax schedules and the government budget restraint, not the workings of the economy, it will be possible to conduct the argument in a setting that is almost model-free.

The claim that deficits have larger long run effects on aggregate demand when bond financed -- or, equivalently, that an open-market purchase is contrac: tionary: -- is somewhat misleading even at the terminological level. In particular, it refers not to the comparative extent to which equal changes in the stocks of money and bonds cause shifts in the aggregate demand schedule, but rather to system-wide reduced-form effects on nominal income in complete systems that 
include aggregate supply functions, government budget restraints, income tax schedules, and specifications regarding capital accumulation, as well as aggregate demand (IS-LM) relations. In addition, "long run" does not mean after lags in consumption, investment, and portfolio behavior have worked themselves out -there are no such lags in the models in question -- but rather that constraints requiring money and bond stocks to be constant are imposed on the system.

Terminology aside, the substantive validity of this second message is highly dubious. The evident basis for its belief is the following implication of the models of Blinder - Solow (1973), Christ (1979, p. 533), Infante - Stein (p. 490), and others: unless an implausible condition is satisfied, the system annot be dynamically stable under the Friedman rule unless bond finance is more expansionary. $5 /$ So a presumption of stability would justify the second message. But reflection upon the meticulous analysis of Christ (1978, 1979) suggests that the correct conclusion is not that the second message is valid, but rather that instability (of certain variables) obtains under the Friedman rule.

To develop an understanding of this result, let us first consider a special model in which it does not quite hold, namely, a purely "Ricardian" model in which the current asset value of government bonds to private agents is precisely offset by agents' recognition of future taxes implied by bond interest payments. As is argued in my cited paper, the stock of bonds does not, in this case, appear as a variable in any of the behavioral equations of a macroeconomic model of the IS, LM, expectational Phillips-curve variety. Nor do tax variables or parameters. Consequently, the system dichotomizes into two distinct blocks. The first of these includes the model's behavioral relations and explains movements in output, $Y$, the price level, $P$, and the nominal interest rate, $r$, conditional upon time paths of the (high-powered) money stock, M, and real government purchases, G. The second block includes tax-transfer schedules and the government budget 


\section{$-5-$}

identity; it explains -- given Y, P, r, M, and G -- movements in tax receipts and the nominal stock of bonds, B. If we combine these last relations we can summarize the second block with the following equation, in which $\mathrm{T}$ and $T$ $(0<\tau<1)$ are the intercept and slope parameters in a nominal tax-transfer schedule:

$$
\mathrm{DM}+\mathrm{DB}=\mathrm{GP}+\mathrm{rB}-\mathrm{T}-\mathrm{T}(\mathrm{YP}+\mathrm{rB}), \quad \mathrm{Dx} \equiv \mathrm{dx} / \mathrm{dt}
$$

Using (1), it can easily be see that the behavior of $B$ is unstable under the monetary rule. In view of the dichotomy described above, (1) can be expressed with $\mathrm{DM}=0$ as

$$
\mathrm{DB}=(1-\tau) \mathrm{rB}+\xi,
$$

in which $\xi$ is exogenous. $6 /$ Thus, with $\mathrm{r}$ exogenous and positive, we have an explosive differential equation in B. The stock of bonds explodes in a positive or negative direction if a deficit or surplus ever occurs. I/

In the pure Richardian case just considered, the explosion of $B$ has no effect on the variables of primary interest -- Y, $P$, and $r$. But suppose that capitalization of future tax liabilities is incomplete, so that the real financial wealth of the private sector is $(M+\phi B) / P$, with $\phi$ "small" but greater than zero. In this nearly Ricardian case, which I henceforth assume to be empirically re1evant, the system does not dichotomize. Consequently, if B explodes, there will be effects on $Y, P$, and $r$ that tend to impart explosive behavior to those variables. The question, then, is whether feedback behavior of $Y, P$, and $r$ into (1) will keep B from exploding.

It seems highly unlikely that such feedback will impart stability to $B$ for the following reasons. With the usual behavioral specifications in which bond wealth $\phi B / P$ is relevant for expenditure (IS) and portfolio (LM) relations, its 
effects on aggregate demand are positive in the former and negative in the latter. Thus the quantitative importance of $B$ on the instantaneous equilibrium values of $Y$ and $P$ would be relatively small even in the absence of future tax capitalization. And with substantial but incomplete capitalization, as herein presumed, these effects will be substantially reduced. Thus functions relating $Y, P$, and $r$ to current values of $B$ will involve weak relationships; the partial derivatives $\tilde{Y}_{1}, \tilde{P}_{1}$, and $\tilde{r}_{1}$ of the reduced-form functions $Y=\tilde{Y}(B, M, \pi), P=\tilde{P}(B, M, \pi)$ and $r=\tilde{r}(B, M, \pi)$ wil1 be smal1 in magnitude. $\underline{8} /$ Therefore, when these functions are used in (1) to obtain the dynamic representation of $B$ in the near-Ricardian case, as in

$$
\mathrm{DB}=[\mathrm{G}-\tilde{T}(\mathrm{Y}, \mathrm{M}, \pi)] \tilde{\mathrm{P}}(\mathrm{B}, \mathrm{M}, \pi)+(1-\tau) \tilde{\mathrm{r}}(\mathrm{B}, \mathrm{M}, \pi) B+\text { constant },
$$

the implied behavior of $B$ will be well-approximated by (2). Thus the behavior of B will be explosive for a wide variety of specifications of the model's behavioral equations. $9 /$

The foregoing result eliminates, it should be emphasized, the reason at hand for thinging that bond-financed deficits would be more expansionary than money-financed deficits (i.e., that open-market purchases would be contractionary). The argument seems to leave us, however, with the conclusion that dynamic instability would prevail under the Friedman rule. It thus seems to support the idea that adoption of the rule would be undesirable.

The instability result has been obtained, however, in a discussion that neglects the effects of economic growth. In a growing economy, equation (1) would continue to hold but the relevant variable for considerations of dynamic stability would not be $B$, but the ratio of bonds to real income, $b=B / Y$. $10 /$ And the appropriate counterpart of (2) would be 
with $\zeta$ analogous to $\xi$ in (2). $11 /$ Furthermore, with money growth as specified by Friedman's rule, it is reasonable to presume that $r$ will be of approximately the same value as the real rate of interest. Then, since the latter should be close in magnitude to the (steady state) rate of output growth, it becomes quite likely (with $T>0$ ) that $(1-T) r-D Y / Y$ will be negative. But that, of course, implies that b will be dynamically stable. Thus, the source of instability provided by the Friedman rule is not present in an economy in which output growth typically proceeds at or above the rate $(1-\tau) r$. The first anti-monetarist message, as well as the second, seems then to be unwarranted.

\section{Concluding Remarks}

It has been argued that the body of literature under discussion provides little reason for skepticism regarding the monetarist proposition (i). Some possibility of instability remains, however, and it must be recognized that while the validity of propositions (i) and (ii) may be necessary, it is not - sufficient, for belief in the desirability of a constant money growth rule. It is possible, even if propositions (i) and (ii) are true, that other policy rules would induce operating characteristics of an economy that would be superior to those yielded by constant money growth.

In this regard, it is interesting to recall that in Friedman's original design of "A Monetary and Fiscal Framework for Economic Stability," it was the stock of bonds, not money, that was to be exogenous to cyclical activity. Money stock changes were to be non-discretionary but were to play the role of financing government deficits and surpluses. Only later, in A Program for Monetary Stability, did Friedman propose an exogenous (constant) rate of monetary growth. The original Friedman rule, it should be noted, apparently possesses all the features of automaticity stressed in Friedman's later writings. Furthermore, with money-financed deficits more expansionary than bond-financed, it would imply a strengthening of 
any stabilizing effects that might be induced by automatic tax responses to fluctuations in nominal income. Its implementation would be difficult, to say the least, but perhaps the original Friedman rule nevertheless warrants renewed consideration. 


\section{$\underline{\text { References }}$}

A.S. Blinder and R.M. Solow, "Does Fiscal Policy Matter?" J. Publ. Econ., Jan./Feb. 1973, 2, 319-37. and , "Does Fiscal Policy Still Matter? A Rep1y," J. Monet. Econ., Nov. 1976, 2, 501-10.

K. Brunner and A.H. Meltzer, "An Aggregate Theory for a Closed Economy," in J.L. Stein, ed., Monetarism, Amsterdam 1976.

C.F. Christ, "Some Dynamic Theory of Macroeconomic Policy Effects on Income and Prices under the Government Budget Restraint," J. Monet. Econ., Jan. 1978, 4, 45-70.

, "On Fiscal and Monetary Policies and the Government Budget Restraint," Amer. Econ. Rev., Sept. 1979, 69, 526-38.

M. Friedman, "A Monetary and Fiscal Framework for Economic Stability," Amer. Econ. Rev., June 1948, 38, 245-64. , A Program for Monetary Stability, New York 1959. , "The Role of Monetary Policy," Amer. Econ. Rev., March 1968, 58, $1-17$.

, A Theoretical Framework for Monetary Analysis, New York 1971.

F.H. Hahn, "Monetarism and Economic Theory," Economica, Feb. 1980, 47, 1-17.

E.F. Infante and J.L. Stein, "Does Fiscal Policy Matter?" J. Monet. Econ., Nov. $1976,2,473-500$.

R.E. Lucas, Jr., "Econometric Testing of the Natural Rate Hypothesis," in 0. Eckstein, ed., The Econometrics of Price Determination Conference, Washington 1972. 
, "Rules, Discretion, and the Role of the Economic Advisor,"

in S. Fischer, ed., Rational Expectations and Economic Policy, Chicago 1980.

B.T. McCallum, "On Macroeconomic Instability from a Monetarist Policy Rule," Economics Letters, $1978,1,121-4$ :

F. Modigliani, "The Monetarist Controversy or, Should We Forsake Stabilization Policies?," American Economic Review, March 1977, 67, 1-19.

J.L. Stein, ed., Monetarism, Amsterdam 1976.

J. Tobin and W. Buiter, "Long-Run Effects of Fiscal and Monetary Policy on Aggregate Demand," in J.L. Stein, ed., Monetarism, Amsterdam 1976.

J. Tobin, "Stabilization Policy Ten Years After," Brookings Papers, No.1, $1980,19-71$ 


\section{FOOTNOTES}

*Professor of Economics, University of Virginia, and Visiting Professor, CarnegieMellon University. I am indebted to Albert Ando, Robert Barro, Alan Blinder, Kar1 Brunner, Car1 Christ, Robert Hodrick, Bob Lucas, A11an Me1tzer, and John Whitaker for helpful comments. Also, I am grateful for the financial support of the National Science Foundation (SES 70-15353).

1/ Friedman's rule also requires that the government budget be balanced on average. For compact recent statements of the rule, see Robert Lucas (1980) and Car1 Christ (1979, p. 534).

2/. This list has deliberately been kept as short as possible, in order to increase its discriminatory power. Its two items correspond to those stressed by Hahn (1980). The discussion presumes a closed economy.

3/ See, for example, the papers and comments in the volume edited by Jerome Stein. The NRH is closely related to the Brunner-Meltzer hypothesis that "the economic system is stable."

4/ See, for example, James Tobin. The same is of course true for formulations involving a "non-inflationary rate of unemployment."

5/ The condition is that the partial derivative of the aggregate demand function with respect to the bond stock be "large" in relation to $1-\tau$, with $\tau=$ marginal income tax rate. But this condition is almost certainly invalid, because of substantial tax capitalization -- see p. 6 below.

6/ If DM is a non-zero constant, then the current argument would be expressed in terms of the bond-money ratio, rather than $B$.

I/ It may be useful to think of $r$ and $\xi$ in (2) as stationary equilibrium values of those variables. Then the result implies local instability. 
8/ In these functions, $\pi$ is the expected rate of inflation. It is taken as exogenous in most of the models under discussion; the effect of rational expectations does not seem to alter the results.

9/ In the Brunner-Meltzer system, the result will obtain with bond finance $(\bar{\mu}=0)$ since my argument implies that -- in their notation (p. 83) -$\epsilon(\mathrm{y}, \mathrm{S} \mid 0, \mathrm{AM})$ is sma 11 .

10/ I am deeply indebted to Albert Ando for calling to my attention the importance of output growth.

11/ To see this, define $m=M / Y, g=G / Y$, and write $(1)$ as $D m+D b+(m+b) D Y / Y=$ $\mathrm{Pg}+(1-\tau) \mathrm{rb}-\mathrm{T} / \mathrm{Y}-\tau \mathrm{P}$. Then impose Friedman's rule by setting $\mathrm{Dm}=0$ and requiring $g, \tau$, and $T / Y$ to be constants. 